\title{
The high-affinity lgG receptor FcyRl modulates peripheral nerve injury-induced neuropathic pain in rats
}

\author{
Yingxia Liang ${ }^{1,2}$, Zhiyu Zhang ${ }^{3}$, Zhaodong Juan ${ }^{1}$, Rui Zhang ${ }^{1}$ and Can Zhang $^{2^{*}}$ (D)
}

\begin{abstract}
The Fc gamma receptor I (FcyRl; CD64) is the high-affinity receptor of the immunoglobulin G protein (IgG). It is usually expressed in immune cells and has recently been identified to distribute in the nervous system and play critical roles in various neurological disorders. Presently, the impacts of FcyRl in neuropathic pain was largely unknown. Here, we aimed to investigate the impacts of FcyRl in neuropathic pain through pain-related neurobehavioral studies and underlying mechanisms by biochemical methods in animal and cell models. Specifically, we first utilized the chronic constriction injury (CCI) rat model that displayed neuropathic pain related symptoms and signs, including thermal hyperalgesia and mechanical allodynia. These neurobehavioral defects were significantly attenuated by the anti-FcyRI antibody, which was associated with reduced levels of neuropeptide substance $P, C_{3}$, and TNF-a. Furthermore, we validated our animal findings using the embryonically neural crestoriginated PC12 cell model. We found that stimulation of the lgG immune complex led to increased levels of FcyRl and inflammatory mediators, which were attenuated by the anti-FcyRl antibody in these cells. Collectively, our results from animal and cell-based studies suggest that FcyRl is a critical player for peripheral nerve injury-induced neuropathic pain by mediating pain-related immunological events, which therefore may provide a new therapeutic target for protection against chronic pain.
\end{abstract}

Keywords: Neuropathic pain, Fc gamma receptor, Anti-FcyRl antibody, Spinal cord, Peripheral nerve injury, Inflammatory mediators

\section{Main text}

Neuropathic pain, resulting from somatosensory nervous system dysfunction, is characterized by allodynia, hyperalgesia and spontaneous pain [1]. Neuropathic pain is closely related to immunological responses [2-5], which commonly displays elevated levels of antigen-specific immunoglobulins, particularly the presence of immune complexes of IgG and/or IgG in serum [6]. Fc-gamma receptors (FcyRs), the receptors of IgG, were typically expressed on immune cells and may trigger effector responses including cytokine production and phagocytosis [7]. Besides immune cells, IgG and Fc $\gamma$ Rs also were identified and distributed on neurons of the central and peripheral nervous system [8-10]. Moreover, FcyRs were increasingly recognized for their involvement in various neurological

\footnotetext{
* Correspondence: Zhang.Can@mgh.harvard.edu

${ }^{2}$ Genetics and Aging Research Unit, McCance Center for Brain Health,

Department of Neurology, MassGeneral Institute for Neurodegenerative

Diseases (MIND), Massachusetts General Hospital and Harvard Medical

School, Charlestown, MA 02129, USA

Full list of author information is available at the end of the article
}

disorders including Alzheimer's diseases, Parkinson's disease, ischemic stroke, and multiple sclerosis [11, 12]. The increased knowledge of Fc $\gamma$ Rs in the nervous system pathophysiology has led to novel preventative and therapeutic strategies for neurological disorders [13]. Fc $\gamma$ RI is the high-affinity IgG receptor of the IgG receptor family proteins [14]. In this study, we investigated the effects of FcyRI on neuropathic pain and inflammatory mediators induced by peripheral nerve injury.

First, we observed that the mechanical and thermal allodynia of neuropathic pain was induced by peripheral nerve injury in rats and lasted for 3 weeks (Fig. 1a). The detailed methods used in this study were described in the Additional file 1. Interestingly, the mechanical hyperalgesia was significantly attenuated after treatment with the antiFc $\gamma R I$ antibody $(4 \mu \mathrm{g} / \mathrm{ml})$ in neuropathic pain rats on postoperative 3, 7, and $14 \mathrm{~d}$, compared with the NP group (Fig. 1a). In the thermal behavioral tests, the latency was significantly extended by the anti-FcyRI antibody in neuropathic pain rats on postoperative 7,14 and $21 \mathrm{~d}$, compared with that in the

(c) The Author(s). 2019 Open Access This article is distributed under the terms of the Creative Commons Attribution 4.0 International License (http://creativecommons.org/licenses/by/4.0/), which permits unrestricted use, distribution, and 


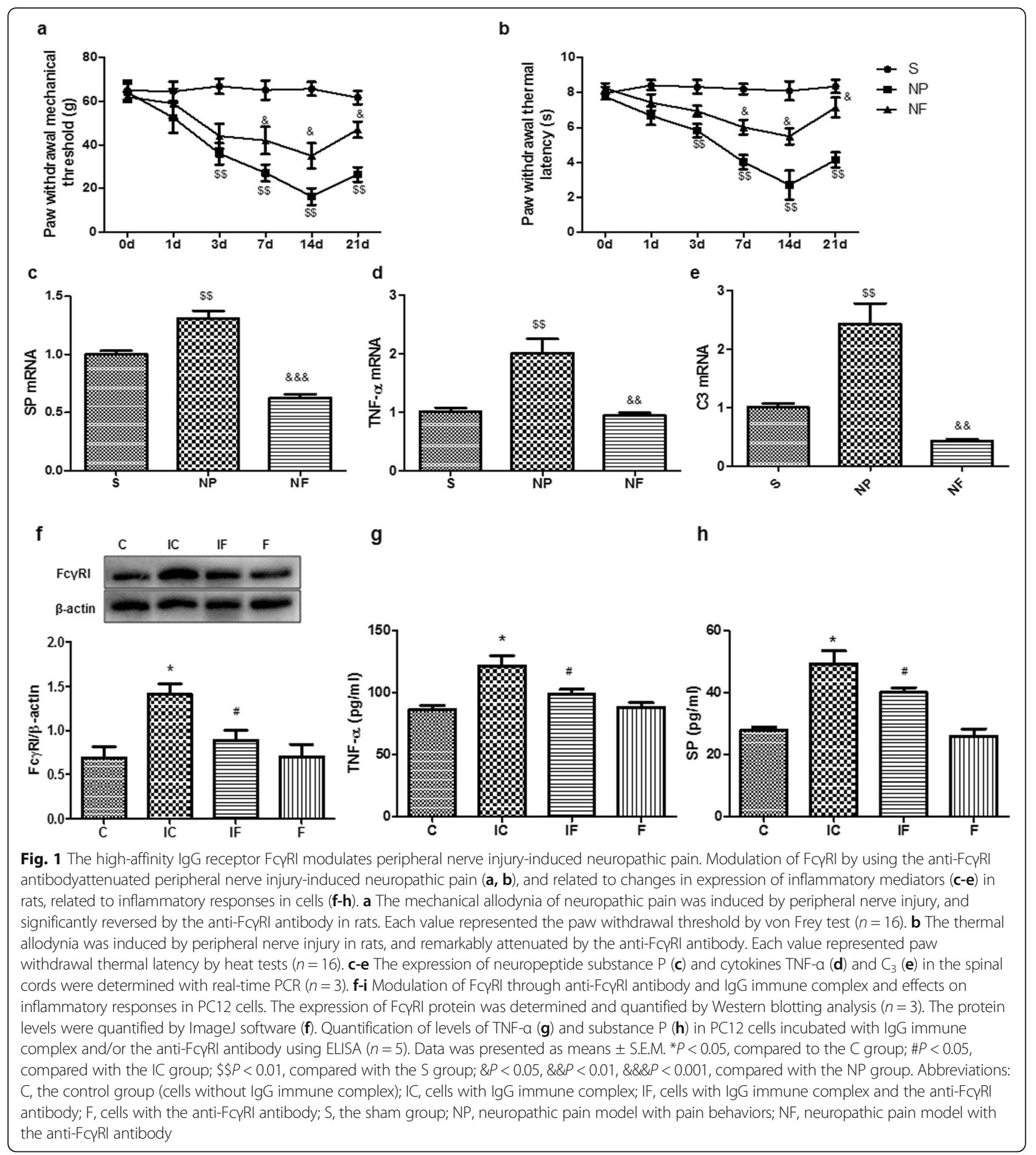

NP group (Fig. 1b). Because peripheral nervous injury leads to an increase of inflammatory mediators, linked to hyperalgesia and other pain behavioral changes [2], we anticipated that modulation of $\mathrm{Fc} \gamma \mathrm{RI}$ will result in mediators changes in our pain model animals. We therefore investigated the influences of FcyRI on inflammatory mediators in the spinal cord of our neuropathic pain modelanimals.
Indeed, we found that the levels of substance $\mathrm{P}, \mathrm{C}_{3}$, and TNF- $\alpha$ were significantly higher in the NP group animals than those in the sham animals, as expected and supported by previous studies [15]. The anti-Fc $\gamma$ RI antibody remarkably decreased the expression of these inflammatory mediators and neuropeptide in the neuropathic pain animals (Fig. 1c-e). 
We next carried out cell-based studies to further investigate our animal-based findings. Specifically, the embryonically rat neural crest-originated $\mathrm{PC} 12$ cells were utilized and subjected to experiments of the following four groups: the control group $(\mathrm{C})$; the IgG immune complex alone (IC, $0.1 \mu \mathrm{g} / \mathrm{ml}$ ); and the group combined with IgG immune complex and anti-FcyRI antibody (IF, IgG immune complex $0.1 \mu \mathrm{g} / \mathrm{ml}$ and the anti-Fc $\gamma R I$ antibody $0.2 \mu \mathrm{g} / \mathrm{ml}$ ) and anti-FcyRI antibody alone (F, $0.2 \mu \mathrm{g} / \mathrm{mL}$ ). We showed that the IgG immune complex significantly up-regulated Fc $\gamma$ RI protein level compared to the control by Western blotting analysis (Fig. 1f). Additionally, the group combined with IgG immune complex and anti-Fc $\gamma$ RI antibody significantly decreased Fc $\gamma$ RI protein levels compared to the IgG immune complex alone (Fig. 1f). There were no significant changes comparing the anti-FcyRI antibody alone to the control. In addition, the IgG immune complex increased the expression of substance P and TNF- $\alpha$ compared to the control, which was attenuated by the addition of antiFc $\gamma$ RI antibody (Fig. 1g-h). Our results from the animals and PC12 cells suggested that other various cell and animal models should be used in future studies to elucidate the mechanisms by which Fc $\gamma$ RI modulates neuropathic pain. Collectively, these results suggested that Fc $\gamma$ RI was involved in the IgG immune complex-induced inflammatory responses in cell-based studies, supporting our animal-based results.

Despite increased understanding of FcyRI underlying the pathophysiology of the neuroimmune system, its effects in neuropathic pain began to be elucidated. We utilized both animal and cell models in this study and showed that FcyRI is a critical player for the peripheral nerve injury-induced neuropathic pain. Importantly, the anti-Fc $\gamma$ RI antibody attenuated pain-related neurobehavioral defects, and normalized changes of inflammatory cytokines. In summary, our studies showed that FcyRI modulates peripheral nerve injury-induced neuropathic pain in animals through regulating inflammatory mediators. Our finding may provide both novel knowledge of the pathogenesis underlyingthe neuropathic pain and may suggest new therapeutic strategies to alleviate pain.

\section{Supplementary information}

Supplementary information accompanies this paper at https://doi.org/10. 1186/s13041-019-0499-3.

Additional file 1: Materials and Methods, Supplementary Figures and Tables

\section{Abbreviations}

g: gram; NP: Neuropathic pain; SP: Substance P

\section{Authors' contributions}

$Y L, Z Z$, and RZ performed most experiments, collected and analyzed data. $Y L, Z J$ and $C Z$ participated in the design of the study. Manuscript was written by $\mathrm{YL}, \mathrm{ZJ}$, and critically reviewed by $\mathrm{CZ}$. All authors read and approved the final manuscript.

\section{Funding}

This work was supported by the National Natural Science Foundation of China (No 81300969), Shandong Provincial Natural Science Foundation of China (No.ZR2017MH066, ZR2012HL27), the Shandong Medical and Health Technology Development Project of China (No. 2017WS581), and the Weifang Medical Doctoral Fund Project of China (No. 2017BSQD03).

Availability of data and materials

Available by contacting the corresponding author for reasonable request.

Ethics approval and consent to participate

All the animal procedures were performed in compliance with the National Institutes of Health Animal Care Guidelines. The experiment protocol used for rats in this study was approved by the Animal Ethical Committee of Weifang Medical University.

Consent for publication

Agreed by all authors.

Competing interests

The authors declare that they have no competing interests.

\section{Author details}

${ }^{1}$ Department of Anesthesiology, Weifang Medical University, Weifang 261053, Shandong, China. ${ }^{2}$ Genetics and Aging Research Unit, McCance Center for Brain Health, Department of Neurology, MassGeneral Institute for Neurodegenerative Diseases (MIND), Massachusetts General Hospital and Harvard Medical School, Charlestown, MA 02129, USA. ${ }^{3}$ Department of Trauma Orthopedics, Shouguang People's Hospital, Weifang 262700,

Shandong, China.

Received: 27 June 2019 Accepted: 11 September 2019

\section{References}

1. Colloca L, Ludman T, Bouhassira D, Baron R, Dickenson AH, Yarnitsky D, Freeman R, Truini A, Attal N, Finnerup NB, et al. Neuropathic pain. Nat Rev Dis Primers. 2017;3:17002.

2. Pinho-Ribeiro FA, Verri WA Jr, Chiu IM. Nociceptor sensory neuron-immune interactions in pain and inflammation. Trends Immunol. 2017;38(1):5-19.

3. Liang $Y X$, Wang NN, Zhang ZY, Juan ZD, Zhang C. Necrostatin-1 ameliorates peripheral nerve injury-induced neuropathic pain by inhibiting the RIP1/ RIP3 pathway. Front Cell Neurosci. 2019;13:211.

4. Zhang C, Ward J, Dauch JR, Tanzi RE, Cheng HT. Cytokine-mediated inflammation mediates painful neuropathy from metabolic syndrome. PLoS One. 2018;13(2):e0192333.

5. Du H, Shi J, Wang M, An S, Guo X, Wang Z. Analyses of gene expression profiles in the rat dorsal horn of the spinal cord using RNA sequencing in chronic constriction injury rats. J Neuroinflammation. 2018;15(1):280

6. Qu L. Neuronal fc gamma receptor I as a novel mediator for lgG immune complex-induced peripheral sensitization. Neural Regen Res. 2012;7(26):2075-9.

7. Nimmerjahn F, Ravetch JV. Fcgamma receptors: old friends and new family members. Immunity. 2006;24(1):19-28.

8. Huang J, Sun X, Mao Y, Zhu X, Zhang P, Zhang L, Du J, Qiu X. Expression of immunoglobulin gene with classical $V$-(D)-J rearrangement in mouse brain neurons. Int J Biochem Cell Biol. 2008:40(8):1604-15.

9. Niu N, Zhang J, Guo Y, Zhao Y, Korteweg C, Gu J. Expression and distribution of immunoglobulin $\mathrm{G}$ and its receptors in the human nervous system. Int J Biochem Cell Biol. 2011;43(4):556-63.

10. Andoh $T$, Kuraishi $Y$. Direct action of immunoglobulin $G$ on primary sensory neurons through fc gamma receptor I. FASEB J. 2004;18(1):182-4.

11. Fuller JP, Stavenhagen JB, Teeling JL. New roles for fc receptors in neurodegeneration-the impact on immunotherapy for Alzheimer's disease. Front Neurosci. 2014;8:235. 
12. Nakahara J, Aiso S. Fc receptor-positive cells in remyelinating multiple sclerosis lesions. J Neuropathol Exp Neurol. 2006;65(6):582-91.

13. Okun E, Mattson MP, Arumugam TV. Involvement of fc receptors in disorders of the central nervous system. NeuroMolecular Med. 2010;12(2):164-78.

14. Barnes N, Gavin AL, Tan PS, Mottram P, Koentgen F, Hogarth PM. FcgammaRI-deficient mice show multiple alterations to inflammatory and immune responses. Immunity. 2002;16(3):379-89.

15. Totsch SK, Sorge RE. Immune system involvement in specific pain conditions. Mol Pain. 2017;13:1744806917724559.

\section{Publisher's Note}

Springer Nature remains neutral with regard to jurisdictional claims in published maps and institutional affiliations.

Ready to submit your research? Choose BMC and benefit from:

- fast, convenient online submission

- thorough peer review by experienced researchers in your field

- rapid publication on acceptance

- support for research data, including large and complex data types

- gold Open Access which fosters wider collaboration and increased citations

- maximum visibility for your research: over $100 \mathrm{M}$ website views per year

At $\mathrm{BMC}$, research is always in progress.

Learn more biomedcentral.com/submissions 